\title{
Analiza zmian obowiązkowego ubezpieczenia odpowiedzialności cywilnej brokera w zakresie dotyczącym minimalnej sumy gwarancyjnej oraz umownego ograniczenia odpowiedzialności zakładów ubezpieczeń
}

\begin{abstract}
Wprowadzenie
Najnowsze rozporządzenie z dnia 12 lutego 2015 r. w sprawie obowiązkowego ubezpieczenia odpowiedzialności cywilnej z tytułu wykonywania działalności brokerskiej weszło w życie 1 czerwca 2015 r. ${ }^{1}$ Określa ono szczególowe warunki obowiązkowego ubezpieczenia odpowiedzialności cywilnej za szkody powstałe z tytułu wykonywania działalności brokerskiej. Warto zauważyć, że jest to kolejne rozporządzenie dostosowujące polskie prawo do wymogów dyrektywy 2002/92/WE w sprawie pośrednictwa ubezpieczeniowego, zwanej w skrócie IMD². Porównując treść wspomnianego rozporządzenia do poprzedniego, można zauważyć jedynie dwie zmiany: określono maksymalną długość okresu ubezpieczenia objętego sumą gwarancyjną na 12 miesięcy oraz uchylono możliwości umownego ograniczenia odpowiedzialności zakładów ubezpieczeń o kwotę nieprzekraczającą 10\% wartości należnego odszkodowania. Można zatem stwierdzić, że istotą wydanego rozporządzenia jest neutralizacja niedociągnięć legislacyjnych dokonanych w trakcie pierwotnego implementowania dyrektywy. Celem niniejszego artykułu będzie analiza wprowadzonych zmian i ich możliwych konsekwencji dla poszkodowanych wykonywaniem usług brokerskich oraz brokerów ubezpieczeniowych.
\end{abstract}

1 Rozporządzenie Ministra Finansów z dnia 12 lutego 2015 r. w sprawie obowiązkowego ubezpieczenia odpowiedzialności cywilnej z tytułu wykonywania działalności brokerskiej, Dz.U. nr 0 poz. 275.

2 Dyrektywa 2002/92/EC Parlamentu Europejskiego i Rady z dnia 9 grudnia 2002 r. w sprawie pośrednictwa ubezpieczeniowego (IMD 1), OJ L 9 z 15.01.2003; dalej dyrektywa IMD. 
Ubezpieczenie odpowiedzialności cywilnej z tytułu wykonywania działalności brokerskiej jest ubezpieczeniem obowiązkowym ${ }^{3}$. Jako ratio legis wspomnianego obowiązku można wskazać, po pierwsze, chęć „zapewnienia skuteczności przepisom prawa odszkodowawczego - zagwarantowania, by w każdym przypadku, gdy osoba ubezpieczona ponosi odpowiedzialność wobec osoby trzeciej, nastąpiło rzeczywiste spełnienie świadczenia odszkodowawczego i to w pełnej (ograniczonej jedynie wysokością sumy gwarancyjnej) wysokości", po drugie, potrzebę ochrony interesów korporacyjnych w postaci budowania zaufania do rynku finansowego ${ }^{4}$.

\section{Wysokość, zakres minimalnej sumy gwarancyjnej oraz długość okresu ubezpieczenia}

Odpowiednio wysoka minimalna suma gwarancyjna pozwala zrealizować gwarancyjną funkcję ubezpieczeń odpowiedzialności cywilnej. Należy przy tym zauważyć, że stopień ochrony interesów poszkodowanych zależy nie tylko od wysokości minimalnej sumy gwarancyjnej, ale również od okresu, który dana suma gwarancyjna ma obejmować. Im dłuższy okres trwania, obejmujący daną minimalną sumę gwarancyjną, tym wyższa powinna być jej wysokość, aby zapewnić poszkodowanym skuteczną realizację roszczeń. $\mathrm{W}$ obecnie obowiązującym rozporządzeniu minimalna suma gwarancyjna ubezpieczenia odpowiedzialności cywilnej, w okresie nie dłuższym niż 12 miesięcy, wynosi równowartość w złotych 1250618 euro w odniesieniu do jednego zdarzenia, którego skutki są objęte umową ubezpieczenia, oraz 1875972 euro w odniesieniu do wszystkich takich zdarzeń. Minimalne sumy gwarancyjne w podanej wysokości obowiązują od 10 stycznia 2014 r. ${ }^{6}$ Można zastanawiać się, czy wymienione minimalne sumy gwarancyjne są odpowiednio wysokie do zapewnienia pełnej realizacji roszczeń poszkodowanych. Warto zauważyć, że wysokość minimalnych sum gwarancyjnych sukcesywnie się zwiększa. Zgodnie z dyrektywą IMD jest ona kontrolowana co 5 lat, a następnie waloryzowana w celu uwzględnienia zmian w europejskim wskaźniku cen konsumpcyjnych, publikowanym w Eurostacie (art. 4 ust. 7 dyrektywy IMD). Wyjściowym pułapem dla wysokości minimalnych sum gwarancyjnych była równowartość w złotych 50000 euro zarówno

3 Art. 22 ust. 1 ustawy z dnia 22 maja 2003 r. o pośrednictwie ubezpieczeniowym, Dz.U. nr 124 poz. 1154; dalej u.p.u.

4 M. Orlicki, Obowiązorve ubezpieczenie odpowiedzialności cywilnej brokerów ubezpieczeniowych, [w:] Broker w świetle praktyki ubezpieczeniowej, red. M. Serwach, Łódź 2012, s. 225; E. Wieczorek, [w:] Prawo ubezpieczeń gospodarczych. Komentarz, t. I, red. Z. Brodecki, M. Serwach, M. Glicz, wydanie 2, Warszawa 2010, s. 1163.

5 § 4 ust. 1 rozporządzenia Ministra Finansów z dnia 12 lutego 2015 r.

6 Rozporządzenie Ministra Finansów z dnia 12 listopada 2013 r. zmieniające rozporządzenie w sprawie obowiązkowego ubezpieczenia odpowiedzialności cywilnej z tytułu wykonywania działalności brokerskiej, Dz.U. 2013 poz. 1495. 
dla jednego, jak i dla wszystkich zdarzeń w 2003 r., a następnie równowartość w złotych 1000341000 euro w odniesieniu do jednego zdarzenia, którego skutki są objęte umową ubezpieczenia, oraz 1500000 euro w odniesieniu do wszystkich takich zdarzeń w 2005 r.

Ustawowe określenie, że minimalna suma gwarancyjna odnosi się do okresu nie dłuższego niż 12 miesięcy, należy uznać za szczególnie istotną zmianę. Dotychczas bowiem możliwa była sytuacja, gdy broker zawarł co prawda umowę ubezpieczenia odpowiedzialności cywilnej na wymaganą wysokość minimalnej sumy gwarancyjnej, jednak czynił to na okres np. 5 lub 10 lat. Takie wydłużenie okresu objętego minimalną sumą gwarancyjną, przy założeniu braku ustawowego obowiązku uzupełniania sumy gwarancyjnej do pierwotnej wysokości, w miarę dokonywania kolejnych wypłat w okresie ubezpieczenia mogło spowodować spadek realnej możliwości zaspokojenia roszczeń poszkodowanego do poziomu np. 100000 zł na jedno zdarzenie. Zaistnienie w praktyce wspomnianej sytuacji było dość prawdopodobne, ponieważ ani w ustawie o pośrednictwie ubezpieczeniowym, ani w rozporządzeniu w sprawie obowiązkowego ubezpieczenia odpowiedzialności cywilnej z tytułu wykonywania czynności brokerskich nie wyrażono expressis verbis obowiązku doubezpieczenia, w przypadku znacznego uszczuplenia sumy gwarancyjnej w okresie ubezpieczenia. Powinność doubezpieczenia można było natomiast wyinterpretować z założenia o racjonalności prawodawcy, argumentując, że skoro ustawodawca ustanowił dany obowiązek, to wymaga rzeczywistego, a nie symbolicznego czy pozornego wypełniania przez ubezpieczenia obowiązkowe ich funkcji ${ }^{7}$. Obecnie nadal możliwe jest zawieranie wieloletnich umów ubezpieczenia odpowiedzialności cywilnej, jednak globalna suma gwarancyjna musi być skorelowana w taki sposób, aby w skali roku spełniać wymogi dotyczące wysokości minimalnej sumy gwarancyjnej.

Pomimo wspomnianych korzystnych dla poszkodowanych zmian przepisów warto zauważyć, że zakres sumy gwarancyjnej nadal odnosi się do zdarzenia, zamiast roszczenia (pojęcie roszczenia expressis verbis pojawia się w dyrektywie IMD, nie występuje tam natomiast pojęcie zdarzenia). Ta z pozoru mało istotna rozbieżność terminologiczna, może powodować znaczące konsekwencje dla możliwości zaspokojenia roszczeń poszkodowanych. $Z$ jednego zdarzenia może wynikać wiele roszczeń, których łączna suma może przekroczyć wysokość minimalnej sumy gwarancyjnej przewidzianej na jedno zdarzenie. W przypadku posługiwania się pojęciem roszczenia możliwe jest zastosowanie wyższej minimalnej sumy gwarancyjnej właściwej dla skutków wszystkich zdarzeń, co jest bardziej korzystne dla poszkodowanego ${ }^{8}$.

Warto przy tym zwrócić uwagę na wspomniane zjawisko wyczerpywania się sumy gwarancyjnej w miarę dokonywania kolejnych wypłat w okresie ubezpieczenia. Mimo że suma gwarancyjna ubezpieczenia odpowiedzialności cywilnej brokera jest wysoka w porównaniu $\mathrm{z}$ innymi zawodami wymagającymi zawarcia obowiązkowego ubezpieczenia

7 M. Orlicki, Ubezpieczenia obowiazkowe, Warszawa 2011, s. 525.

8 M. Orlicki, Obowiqzkowe ubezpieczenie..., op. cit., s. 230. 
odpowiedzialności cywilnej (jedynie multiagent ma obowiązek zawarcia umowy ubezpieczenia odpowiedzialności cywilnej na minimalną sumę gwarancyjną w identycznej wysokości jak broker, natomiast np. u adwokatów, radców prawnych i notariuszy wynosi ona równowartość w złotych 50000 euro w odniesieniu do jednego zdarzenia, którego skutki są objęte umową ubezpieczenia, nie wspominając już o zawodach, w których nie określa się ustawowo minimalnej sumy gwarancyjnej), to relatywnie może okazać się zbyt niska nawet dla zaspokojenia roszczeń poszkodowanych z wyższej minimalnej sumy gwarancyjnej właściwej dla skutków wszystkich zdarzeń9. Paradoksalnie określenie górnej granicy odpowiedzialności ubezpieczyciela nie precyzując, iż suma gwarancyjna przysługuje na każde zdarzenie, może być bardziej korzystne dla brokera niż dla poszkodowanych, ponieważ ogranicza ewentualną kumulację roszczeń ${ }^{10}$. W tym względzie potencjalna zmiana polegająca na zastąpieniu pojęcia „zdarzenia” terminem „roszczenie” $\mathrm{w}$ rozporządzeniu w sprawie obowiązkowego ubezpieczenia odpowiedzialności cywilnej z tytułu wykonywania działalności brokerskiej może nie przynieść oczekiwanego rezultatu w postaci poprawy sytuacji poszkodowanych.

\section{Umowne ograniczenie odpowiedzialności zakładów ubezpieczeń o kwotę nieprzekraczającą 10\% wartości należnego odszkodowania}

Wprowadzenie wysokich minimalnych sum gwarancyjnych z pewnością korzystnie wpływa na sytuację potencjalnych poszkodowanych wykonywaniem usług brokerskich, należy jednak pamiętać, że z punktu widzenia brokerów wiąże się ono z kosztami w postaci konieczności zapłaty przez nich odpowiednio wysokiej składki ubezpieczeniowej. Według szacunków zakładów ubezpieczeń takie składki mogą wynosić nawet kilkadziesiąt tysięcy złotych, co uprzywilejowuje duże podmioty wykonujące działalność brokerską ${ }^{11} . Z$ obawy, że narzucone przez prawodawstwo unijne, wysokie jak na realia polskiego rynku ubezpieczeniowego, minimalne sumy gwarancyjne negatywnie wpłyną na kondycję podmiotów oferujących usługi brokerskie, wprowadzono udogodnienie dla brokerów, polegające na możliwości umownego ograniczenia odpowiedzialności zakładów

9 Rozporządzenie Ministra Finansów z dnia 12 lutego 2015 r w sprawie obowiązkowego ubezpieczenia odpowiedzialności cywilnej z tytułu wykonywania czynności agencyjnych, Dz.U. nr 0 poz. 276; rozporządzenie Ministra Finansów z dnia 11 grudnia 2003 r. w sprawie obowiązkowego ubezpieczenia odpowiedzialności cywilnej adwokatów, Dz.U. nr 217 poz. 2134; rozporządzenie Ministra Finansów z dnia 11 grudnia 2003 r. w sprawie obowiązkowego ubezpieczenia odpowiedzialności cywilnej radców prawnych, Dz.U. nr 217 poz.2135; rozporządzenie Ministra Finansów z dnia 11 grudnia 2003 r. w sprawie obowiązkowego ubezpieczenia odpowiedzialności cywilnej notariuszy, Dz.U. nr 218 poz. 2148.

10 E. Wieczorek, [w:] Prawo ubezpieczeń gospodarczych..., op. cit., s. 1164.

11 P. Bałasz, K. Szaniawski, Ustawa o pośrednictwie ubezpieczeniowym. Komentarz, Kraków 2005, s. 125. 
ubezpieczeń o kwotę nieprzekraczającą 10\% wartości należnego odszkodowania. Takie rozwiązanie, będące w istocie franszyzą redukcyjną, budziło jednak wiele uzasadnionych wątpliwości dotyczących naruszenia interesów poszkodowanych ${ }^{12}$. Poszkodowani w przypadku zastosowania takiej klauzuli przez brokera mogli w skrajnym wypadku liczyć na wypłatę 90\% wartości należnego im odszkodowania.

W obecnym rozporządzeniu z dnia 12 lutego 2015 r. w sprawie obowiązkowego ubezpieczenia odpowiedzialności cywilnej z tytułu wykonywania działalności brokerskiej zrezygnowano ze wspomnianej możliwości umownego ograniczenia odpowiedzialności zakładów ubezpieczeń o kwotę nieprzekraczającą 10\% wartości należnego odszkodowania. Takie rozwiązanie pozytywnie wpłynęło na stan ochrony poszkodowanych wykonywaniem usług brokerskich, jednak pogorszyło sytuację samych brokerów. Pomimo zrezygnowania przez ustawodawcę ze wspomnianej franszyzy redukcyjnej w aktualnym stanie prawnym możliwe jest korzystne ułożenie stosunków pomiędzy stronami, pozwalające brokerom zredukować wysokość płaconej składki, nie przerzucając ryzyka na poszkodowanych. Można zaproponować za M. Orlickim regulację polegającą na zezwoleniu przez ustawodawcę na zastrzeżenie franszyzy integralnej w stosunku wewnętrznym, pomiędzy ubezpieczycielem a ubezpieczonym brokerem ${ }^{13}$. W przypadku wystąpienia szkody, gdyby jej wartość przekraczała wysokość franszyzy redukcyjnej, poszkodowany mógłby otrzymać odszkodowanie od zakładu ubezpieczeń w pełnej wysokości, przy czym roszczenie regresowe zakładu ubezpieczeń wobec brokera byłoby nieuprawnione. Natomiast w sytuacji gdyby franszyza integralna nie była przekroczona, zakład ubezpieczeń wypłacałby poszkodowanym odszkodowanie w pełnej wysokości, a następnie zwracałby się z roszczeniem regresowym do brokera.

Należy zwrócić uwagę, że rezygnacja z możliwości umownego ograniczenia odpowiedzialności zakładów ubezpieczeń może okazać się nie do końca korzystna dla poszkodowanych, jeśli rozważy się możliwość przerzucenia przez brokerów kosztów wyższych składek ubezpieczenia odpowiedzialności cywilnej na potencjalnych poszkodowanych wykonywaniem usług brokerskich. Aby zminimalizować to ryzyko, warto wspomnieć o nowej dyrektywie w sprawie pośrednictwa ubezpieczeniowego (Insurance Distribution Directive, IDD), która weszła w życie 23 lutego 2016 r. (państwa członkowskie mają czas na jej implementację do 23 lutego 2018 r. $)^{14}$. Przewiduje ona obligatoryjne ujawnianie informacji na temat charakteru wynagrodzenia otrzymanego przez pośredników ubezpieczeniowych w związku z umową ubezpieczenia (art. 19 ust. 1 lit. d IDD). W ramach wspomnianej informacji pośrednik ubezpieczeniowy powinien wskazać, czy jego wy-

12 Cf. M. Orlicki, Obowiqzkowe ubezpieczenie..., op. cit., s. 233.

13 Ibidem.

14 Dyrektywa Parlamentu Europejskiego i Rady (UE) 2016/97 z dnia 20 stycznia 2016 r.w sprawie dystrybucji ubezpieczeń (wersja przekształcona) (tekst mający znaczenie dla EOG), Dz.Urz. UE z dnia 2.02.2016, L 26/19. 
nagrodzenie przybiera formę: honorarium, rozumianego jako wynagrodzenie płacone bezpośrednio przez poszukującego ochrony ubezpieczeniowej; prowizji dowolnego rodzaju, rozumianej jako wynagrodzenie uwzględnione w kwocie składki ubezpieczenia, jakiegokolwiek innego rodzaju wynagrodzenia, w tym korzyści ekonomicznej jakiegokolwiek rodzaju oferowanej lub przekazywanej w związku z umową ubezpieczenia, czy też wynagrodzenia stanowiącego połączenie którychkolwiek z wymienionych rodzajów wynagrodzenia (art. 19 ust. 1 lit. e IDD). Przy czym pośrednik ubezpieczeniowy jest zobowiązany także ujawniać informacje dotyczące jakiekolwiek płatności innej niż bieżące składki i planowe płatności, których poszukujący ochrony ubezpieczeniowej dokonuje po zawarciu umowy ubezpieczenia (art. 19 ust. 3 IDD). Wspomniane przepisy dyrektywy IDD umożliwiają potencjalnym poszkodowanym wykonywaniem działalności brokerskiej zorientowanie się, czy poszczególne składniki wynagrodzenia brokera, nie są zbyt wysokie w stosunku do ponoszonych kosztów. Wydaje się jednak, że tak precyzyjna regulacja obowiązków informacyjnych brokera nie jest konieczna, ponieważ brokerom ubezpieczeniowym jako grupie zawodowej zależy na budowaniu zaufania do rynku usług brokerskich poprzez rzetelne wykonywanie działalności brokerskiej, a poczucie bezpieczeństwa klientów z pewnością wzmacnia to zaufanie.

\section{Podsumowanie}

Można przyjąć, że wydane niedawno rozporządzenie dotyczące obowiązkowego ubezpieczenia odpowiedzialności cywilnej z tytułu wykonywania czynności brokerskich usunęło prawie wszystkie istotne niedociągnięcia legislacyjne powstałe przy pierwotnym implementowaniu dyrektywy IMD. Doprecyzowanie maksymalnej długości okresu ubezpieczenia, objętego sumą gwarancyjną na 12 miesięcy, uniemożliwiło ewentualne manipulacje wysokością sumy gwarancyjnej na niekorzyść poszkodowanego. Podobnie uchylenie możliwości umownego ograniczenia odpowiedzialności zakładów ubezpieczeń o kwotę nieprzekraczającą 10\% wartości należnego odszkodowania zagwarantowało perspektywę zaspokojenia poszkodowanego w 100\%, niezależnie od tego, jak wysoką składkę z tytułu ubezpieczenia odpowiedzialności cywilnej płacił broker. Jako jedyne niedociągnięcie można wskazać pozostawienie przez ustawodawcę sum gwarancyjnych obejmujących skutki danego zdarzenia, zamiast danego roszczenia, co może doprowadzić do wypłaty odszkodowania w niepełnej wysokości, ograniczonego przez wysokość minimalnej sumy gwarancyjnej przypadającej na skutki jednego zdarzenia.

Reasumując, można stwierdzić, że wprowadzone zmiany zmierzają do ograniczenia ryzyka potencjalnych poszkodowanych wykonywaniem usług brokerskich. Należy przy tym mieć świadomość, że zwiększenie bezpieczeństwa poszkodowanych pociąga za sobą wzrost kosztów usług po stronie brokerów. Wydaje się jednak, że budując klimat zaufania do brokerów ubezpieczeniowych, stwarza się poczucie bezpieczeństwa, które 
może zachęcić klientów do szerszego korzystania z usług brokerów, a w konsekwencji przyczynić się do dynamicznego rozwoju tego rynku. Warto też pamiętać o tym, że ubezpieczenie odpowiedzialności cywilnej brokerów ubezpieczeniowych jest tylko jedną z opcji zapewnienia bezpieczeństwa poszkodowanym. Być może dobrym rozwiązaniem przy okazji implementowania dyrektywy IDD byłoby stworzenie brokerom możliwości wyboru instrumentu zabezpieczenia roszczeń, chociażby w postaci gwarancji bankowej czy ubezpieczeniowej, by mogli zabezpieczeć roszczenia poszkodowanych w dogodny dla siebie sposób.

\section{Literatura}

Bałasz P., Szaniawski K., Ustawa o pośrednictwie ubezpieczeniowym. Komentarz, Kraków 2005.

Orlicki M., Obowiqzkowe ubezpieczenie odpowiedzialności cywilnej brokerów ubezpieczeniowych, [w:] Broker w świetle praktyki ubezpieczeniowej, red. M. Serwach, Łódź 2012.

Orlicki M., Ubezpieczenia obowiazkowe, Warszawa 2011.

Prawo ubezpieczeń gospodarczych. Komentarz, t. I, red. Z. Brodecki, M. Serwach, M. Glicz, wyd. II, Warszawa 2010.

Dyrektywa 2002/92/EC Parlamentu Europejskiego i Rady z dnia 9 grudnia 2002 r. w sprawie pośrednictwa ubezpieczeniowego (IMD 1), OJ L 9 z 15.01.2003.

Dyrektywa 2016/97 Parlamentu Europejskiego i Rady (UE) z dnia 20 stycznia 2016 r. w sprawie dystrybucji ubezpieczeń (wersja przekształcona) Dz.Urz. UE z 2.02.2016, L 26/19.

Rozporządzenie Ministra Finansów z dnia 11 grudnia 2003 r. w sprawie obowiązkowego ubezpieczenia odpowiedzialności cywilnej adwokatów, Dz.U. 2003 nr 217 poz. 2134.

Rozporządzenie Ministra Finansów z dnia 11 grudnia 2003 r. w sprawie obowiązkowego ubezpieczenia odpowiedzialności cywilnej radców prawnych, Dz.U. 2003 nr 217 poz. 2135.

Rozporządzenie Ministra Finansów z dnia 11 grudnia 2003 r. w sprawie obowiązkowego ubezpieczenia odpowiedzialności cywilnej notariuszy, Dz.U. 2003 nr 218 poz. 2148.

Rozporządzenie Ministra Finansów z dnia 12 lutego 2015 r w sprawie obowiązkowego ubezpieczenia odpowiedzialności cywilnej z tytułu wykonywania czynności agencyjnych, Dz.U. nr 0 poz. 276.

Rozporządzenie Ministra Finansów z dnia 12 lutego 2015 r w sprawie obowiązkowego ubezpieczenia odpowiedzialności cywilnej z tytułu wykonywania działalności brokerskiej, Dz.U. nr 0 poz. 275. 
Rozporządzenie Ministra Finansów z dnia 12 listopada 2013 r. zmieniające rozporządzenie w sprawie obowiązkowego ubezpieczenia odpowiedzialności cywilnej z tytułu wykonywania działalności brokerskiej, Dz.U. 2013 poz. 1495.

Ustawa z dnia 22 maja 2003 r. o pośrednictwie ubezpieczeniowym, Dz.U. nr 124 poz. 1154.

\section{SUMMARY}

The analysis of the civil liability of an insurance broker on the minimum insurance guaranteed sum against liability and the contractual limitation of insurance undertaking liability

The article is devoted to the analysis of the law regime regulating the professional indemnity insurance issues of insurance intermediaries. The Ordinance of the Finance Minister on the civil liability matters of insurance mediation business, which entered into force 1 July 2015 lays down the civil liability risks for insurance intermediaries pursuing their activity in Poland. The Ordinance, in comparison to its repealed version, takes down the possibility of a contractual limitation of insurance undertaking liability to the criterion of $10 \%$ of the redress value and corrects the maximum insurance cover period of (limited to 12 months). It has been found that a wrong transposition of directive No. 2002/92/EC of the European Parliament and of the Council of 9 December 2002 on insurance mediation was the cause of such legislative activity. In addition to making an exhaustive analysis of this amendment, an attempt is made to assess it for the sake of the market share of recipients of insurance services requiring special protection (consumers) and intermediaries (insurance brokers).

Keywords: broker, insurance, insurance intermediaries, insurance distribution directive, civil liability

Marta Karpińska, Adam Mickiewicz University Poznań, Faculty of Law and Administration, Al. Niepodległości 53, 61-714 Poznań, e-mail: marta.karpinska@amu.edu.pl. 